\title{
Too much of a good thing: phosphorus over-fertilisation in rehabilitated landscapes of high biodiversity value
}

\author{
M Tibbett University of Reading, UK \\ R O'Connor University of Reading, UK \\ MI Daws University of Reading, UK
}

\begin{abstract}
Fertilisers supply essential nutrients lacking in post-mining substrates in nearly all terrestrial rehabilitation schemes. Regulators typically require the rapid revegetation of post-mining lands as an indicator of early rehabilitation success, mapping to perceived pathways of successful ecosystem recovery. However, we will show how this approach can lead to poorer outcomes in terms of vegetation composition and potentially, long-term issues in ecosystem biogeochemistry.

Many mines exist in remote areas and on highly weathered, ancient, nutrient poor soils. Examples of these are the Fynbos of South Africa, the western and northern forests of Australia, the Campos rupestres of South America, and many tropical areas. Typically, restoration requirements in these areas require the return of a native vegetation community that existed prior to mining. This is particularly common for surface strip mining where large areas of land are cleared of vegetation annually. In this paper, we show how, where, and why over-fertilisation can occur.

Based on examples from western and northern Australia, we demonstrate that the application of phosphoruscontaining fertilisers to these nutrient depleted soils can result in long-term elevated soil phosphorus, with species-specific negative impacts on plant health and growth. We show the rehabilitation benefits that can be gained by judicious fertilisation in terms of vegetation community structure and ecosystem development. Finally, to assess where these findings may have wider applicability, we identify further global regions with nutrient depleted soils, high plant diversity, and current or prospective strip mining operations.
\end{abstract}

Keywords: rehabilitation, phosphorus, competition, fertiliser, legumes, nitrogen, biodiversity, OCBILs

\section{Introduction}

The highly disturbed landscapes of post-mining environments are extreme examples of land degradation that are only surpassed by those of large-scale natural events such as desertification, glaciation, volcanism, and meteorite impacts. When under proper regulatory control and public scrutiny, mining companies make great efforts to rehabilitate these lands into valued self-sustaining ecosystems. However, modern, large-scale strip mining and related activities alter landscapes and lead to ecosystems that-despite the miner's best effortsare tangibly different to the surrounding pre-mining environment.

Fertilisers supply essential nutrients lacking in post-mining substrates in nearly all terrestrial rehabilitation schemes. Regulatory requirements typically oblige the rapid revegetation of post-mining lands as an indicator of expeditious rehabilitation activity, mapping to perceived pathways of successful ecosystem recovery. While well intentioned and having clear benefits in substrate stabilisation and soil carbon supply, this can lead to poor outcomes in terms of vegetation composition and, potentially, long-term issues in ecosystem biogeochemistry.

Several ore types are typically strip-mined and include bauxite, iron, mineral sands, gypsum, and phosphate resources. Of these, bauxite, iron, and mineral sands most often appear either in very ancient, weathered landscapes or younger, nutrient-poor sands. In these ecosystems, it is common to find highly diverse native 
plant communities that have adapted to survive in these conditions that are characterised by extremely low phosphorus (P) supply in the soil. Examples of these landscapes include the Fynbos of South Africa, the western and northern forests of Australia, and the Campos rupestres of South America, along with many tropical areas. In fact, it is common to find mining and biodiversity in conflict (Tibbett 2015). Areas of the land surface that contain commercially viable mineral resources are often those that contain high levels of biodiversity and species endemism (Sonter et al. 2018) and these often occur on some of the world most ancient landscapes, e.g. in bauxite mining (Tibbett 2010).

Typically, rehabilitation requirements in these areas are the return of a native vegetation community that existed prior to mining. This is particularly common for surface strip mining where large areas of land are cleared of vegetation annually. In this paper, we show how, where, and why over-fertilisation can occur. We will show the rehabilitation benefits that can be gained by judicious fertilisation in terms of plant health, vegetation community structure, and ecosystem development. Based primarily on Australian plants, soils, and ecosystems, we investigated:

1. The evidence for long-term effects of soil P fertilisation on available soil P.

2. Physiological problems that can arise in some species of plants that are subject to $P$ toxicity.

3. How these phenomena lead to asymmetric competition between species, driven particularly by legumes.

4. To what extent this might have implications for biodiverse native species rehabilitation globally.

\section{Context and evidence}

We have explored a number of data sources from published and unpublished experiments and field assessments, primarily from Western Australia and the Northern Territory. These are divided into four main categories:

1. Evidence for fertiliser $P$ to endure in soils.

2. Evidence for phosphorus toxicity in plants.

3. Evidence for undesirable plant community outcomes.

4. Global analysis of strip mining in P-deplete, biodiverse landscapes.

\subsection{Evidence for fertiliser phosphorus to endure in soils}

$\mathrm{P}$ fertiliser is almost ubiquitously applied to all post-mining rehabilitation schemes, along with nitrogen (N) potassium (K), and micronutrients, as deemed necessary. $\mathrm{N}$ is a mobile nutrient in soil and can be rapidly lost from rehabilitated sites through leaching or denitrification (e.g. Banning et al. 2008). Both $\mathrm{K}$ and $\mathrm{P}$ are immobile nutrients, with $P$ in particular having several mechanisms to bind to colloids, form stable sesquioxides, or transform to a range of organic forms (Sanyal \& de Datta 1991; Spain et al. 2018; Brenner et al. 2019). We have shown that soon after $P$ fertiliser application and after regular application over many years, $\mathrm{P}$ remains in the top soil and can be highly stratified (George et al. 2006; Ryan et al. 2017). In the longer-term, it seems that applied $\mathrm{P}$ may be quite persistent or even accumulate in topsoil as part of a modified biogeochemical process in the post-mining incipient soils (Standish et al. 2010; Spain et al. 2018).

In the jarrah forests of Western Australia, several fertiliser-based field experiments established at Boddington bauxite mine and on Alcoa's mine leases, give consistent results on the fate of applied P fertiliser (Table 1). The details of these experiments are too varied and complex to describe here, but details can be found in Ward (2000), Morley et al. (2004), Braimbridge \& Tibbett (2005), Standish et al. (2008), Tibbett \& George (2010), Daws et al. (2014), Daws et al. (2015), Daws and Richardson (2015), and Daws et al. (2019a). In these experiments, Colwell P was measured (as a standard measurement of available soil P) after application with P-based fertilisers comprising either single superphosphate (SSP) or di-ammonium phosphate (DAP). These were applied at rates varying from 10 to $120 \mathrm{~kg} \mathrm{ha}^{-1}$ elemental $P$ and assessed between 1 and 17 years after 
application. From these complimentary studies, it is clear that even at the lowest rates of $\mathrm{P}$ fertiliser addition, available soil $P$ is doubled compared to most unfertilised rehabilitation and native forest sites. Under higher $\mathrm{P}$ application rates, available $\mathrm{P}$ can be more than an order-of-magnitude higher compared to soils where no $P$ was added (see also Daws et al. 2019b; this volume). The short-term increases in available P combined with longer-term significant enduring surpluses of $P$ is further supported by recent work from a restored tropical eucalypt forest chronosequence in the Northern Territory of Australia (Spain et al. 2018). This study of forest soil $\mathrm{P}$ biogeochemistry found ongoing net increases in near-surface concentrations of $\mathrm{P}$ over a 26-year period, indicating ever-increasing available $P$ in a judiciously fertilised rehabilitated forest system compared to the native forest soils.

Table 1 Soil available-(Colwell)P in relation to the application rate of P-based fertilisers (single superphosphate [SSP] and di-ammonium phosphate [DAP]), and time since application, for two bauxite mines in the Jarrah Forest of southwest Western Australia. All the data is for broadcast fertiliser application. The data for Boddington bauxite mine is for a soil depth of $0-5 \mathrm{~cm}$ and the Alcoa data for 0-10 cm depth (*Ward 2000; †Morley et al. 2004; "Standish et al. 2008; \#Daws et

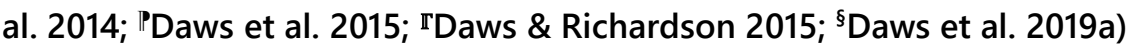

\begin{tabular}{|c|c|c|c|c|c|c|c|c|c|}
\hline \multirow[b]{2}{*}{ 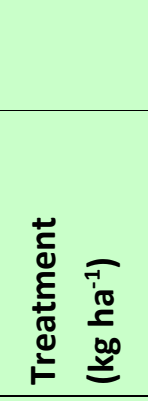 } & \multicolumn{3}{|c|}{$\begin{array}{l}\text { Boddington } \\
\text { bauxite mine }\end{array}$} & \multicolumn{6}{|c|}{ Alcoa mining lease } \\
\hline & 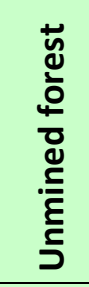 & 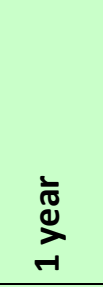 & 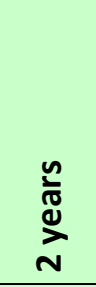 & 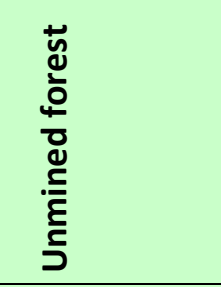 & 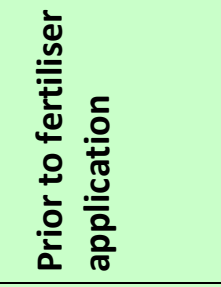 & $\begin{array}{l}n \\
\\
\vdots \\
\vdots \\
\xi \\
\vdots \\
m\end{array}$ & 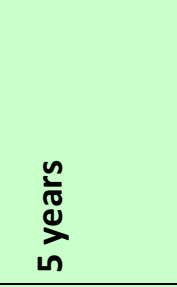 & 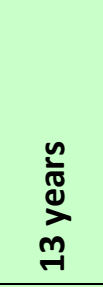 & 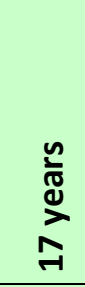 \\
\hline 0 & 2 & 2.0 & 2.0 & $2.6^{*}, 2^{\#}, 4.5^{+}$ & $2^{\ddagger}, 1.7 \mathbb{T}, 1.8^{*}$ & $3.5^{\mathbb{P}}$ & $3.3^{\ddagger},<2.0^{\mathbb{P}}$ & $4.0^{\#}$ & $3.7^{\S}$ \\
\hline $10 \mathrm{SSP}$ & & & & & & & $4.4^{\ddagger}$ & & \\
\hline 20 SSP & & & & & & & $9.2^{\ddagger}$ & & \\
\hline 40 SSP & & 26.3 & 44.0 & & & & $26.0^{\ddagger}$ & & \\
\hline 10 DAP & & & & & & & $6.0^{\ddagger}$ & & \\
\hline 20 DAP & & & & & & $6.6^{\mathbb{P}}, 15.2^{\mathbb{T}}$ & $7.0^{\ddagger}, 3.0^{\mathbb{P}}$ & & $4.2^{\S}$ \\
\hline $40 \mathrm{DAP}$ & & 6.0 & 9.0 & & & $29 \pi$ & $13.8^{\ddagger}$ & & \\
\hline 80 DAP & & & & & & $17.5^{\mathbb{P}}$ & $10.3^{\mathbb{P}}$ & $11.5^{\#}$ & $7.4^{\S}$ \\
\hline $120 \mathrm{DAP}$ & & & & & & & & $14.5^{\#}$ & \\
\hline
\end{tabular}

\subsection{Evidence for phosphorus toxicity in plants}

Soils depleted in nutrients are typically found in ancient, highly weathered soils (Handreck 1997; Lambers et al. 2008). Many plant species in these environments have specialised adaptations, such as root clusters, mycorrhizal symbioses, and exudation of carboxylates (organic acids) and phosphatases, for acquiring $\mathrm{P}$ (Lambers et al. 2006, 2008). Most plant species can regulate excess $P$ supply by down-regulating high-affinity $\mathrm{P}$ transporters that bring phosphate ions from soil solution into roots under low $\mathrm{P}$ conditions (Raghothama 1999; Marschner 1995), however, species that evolved in P-impoverished soils have a poor ability to regulate their $\mathrm{P}$ uptake in this way. These plants can be sensitive to $\mathrm{P}$ toxicity when the $\mathrm{P}$ supply is increased far beyond naturally occurring edaphic concentrations, as is the case under fertilisation (Shane et al. 2004; Handreck 1991; Lambers et al. 2002; Pang et al. 2010; de Campos et al. 2013). However, many of these studies on responses to applied $\mathrm{P}$ have focused either on Proteaceae or on species from the naturally P-deficient soils 
of southwest Western Australia (or both). There is a need to investigate plant responses to applied P in other nutrient deficient regions.

We conducted an experiment based on two woody species from the Great Western Woodlands of Western Australia (Atriplex nummularia and Eucalyptus torquata). Atriplex nummularia is a perennial halophyte species and is a large woody shrub (up to $3 \mathrm{~m}$ ) known commonly as oldman saltbush. A native to Australia, it is hardy, thriving in saline and alkaline soils in arid and semi-arid inland regions. Eucalyptus torquata is a small tree (up to $11 \mathrm{~m}$ ) commonly known as coral gum or Coolgardie gum, and is endemic to Western Australia. These species are candidates for rehabilitation schemes that will likely employ high P fertiliser application as conventional practice.

In our experiment, both plant species were very responsive to $\mathrm{P}$ at low amendment rates, however, at $\mathrm{P}$ concentrations greater than $15 \mathrm{mg} \mathrm{kg}^{-1}$, the response changed (Figure 1). For Atriplex nummularia, dry mass accumulation did not increase with further $\mathrm{P}$ additions. However, for Eucalyptus torquata dry mass accumulation declined as the $\mathrm{P}$ concentration increased above $16 \mathrm{mg} \mathrm{kg}^{-1}$. For both the study species, $\mathrm{P}$ concentrations increased with increasing $P$ application. Although there is great variation in the tissue concentration at which $\mathrm{P}$ becomes toxic to plants, concentrations less than $4 \mathrm{mg} \mathrm{g}^{-1}$ are known to induce toxicity symptoms (Shane et al. 2004). These data suggest a potential risk that-in a rehabilitation contextexcess applied $\mathrm{P}$ may decrease growth rates for some plant species. Therefore, fertiliser addition has the potential to have unpredictable impacts on competitive dynamics and affect developing plant communities (Williams et al. 2019).

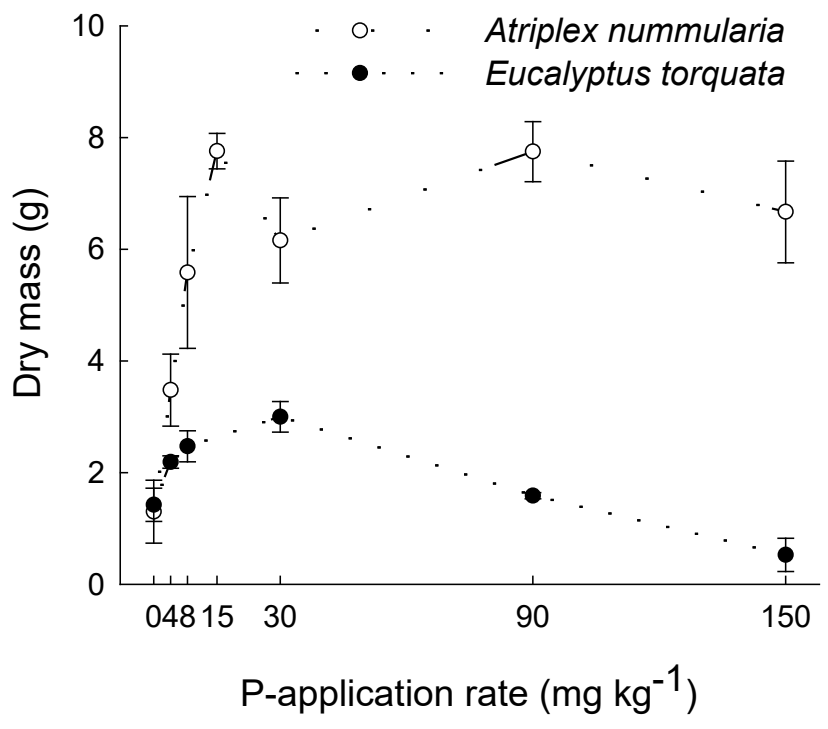

(a)

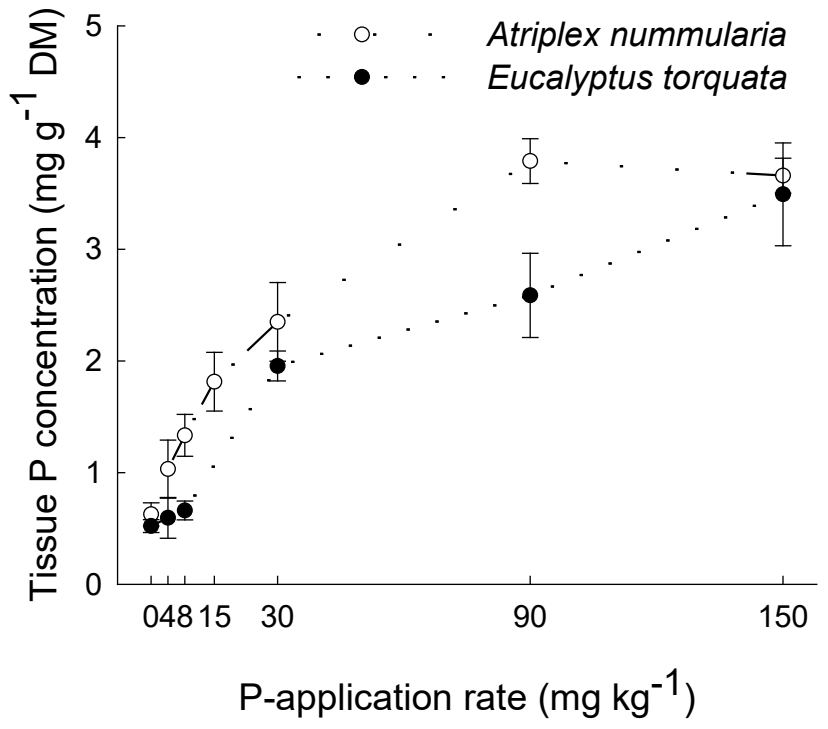

(b)

Figure 1 The effect of $P$ applied on (a) dry mass and (b) tissue $P$ concentration of two woody species from the Great Western Woodlands (Atriplex nummularia and Eucalyptus torquata) grown for 136 days in washed river sand at a range of external soil P concentrations. Means +/- standard error

In a further experiment, we tested similar P dose responses of two Jarrah Forest species; Acacia celastrifolia, a fast-growing pioneer species, and Eucalyptus marginata (jarrah), a keystone tree species of the Jarrah Forest. After 187 days of growth, we found Acacia celastrifolia had responded very positively to $\mathrm{P}$ amendments at low application rates and continued to accumulate greater plant mass, although not so strongly, at higher application rates (Figure 2). Eucalyptus marginata was also responsive at low concentrations but showed a toxicity response at high concentration of amended $\mathrm{P}$, with higher application. 

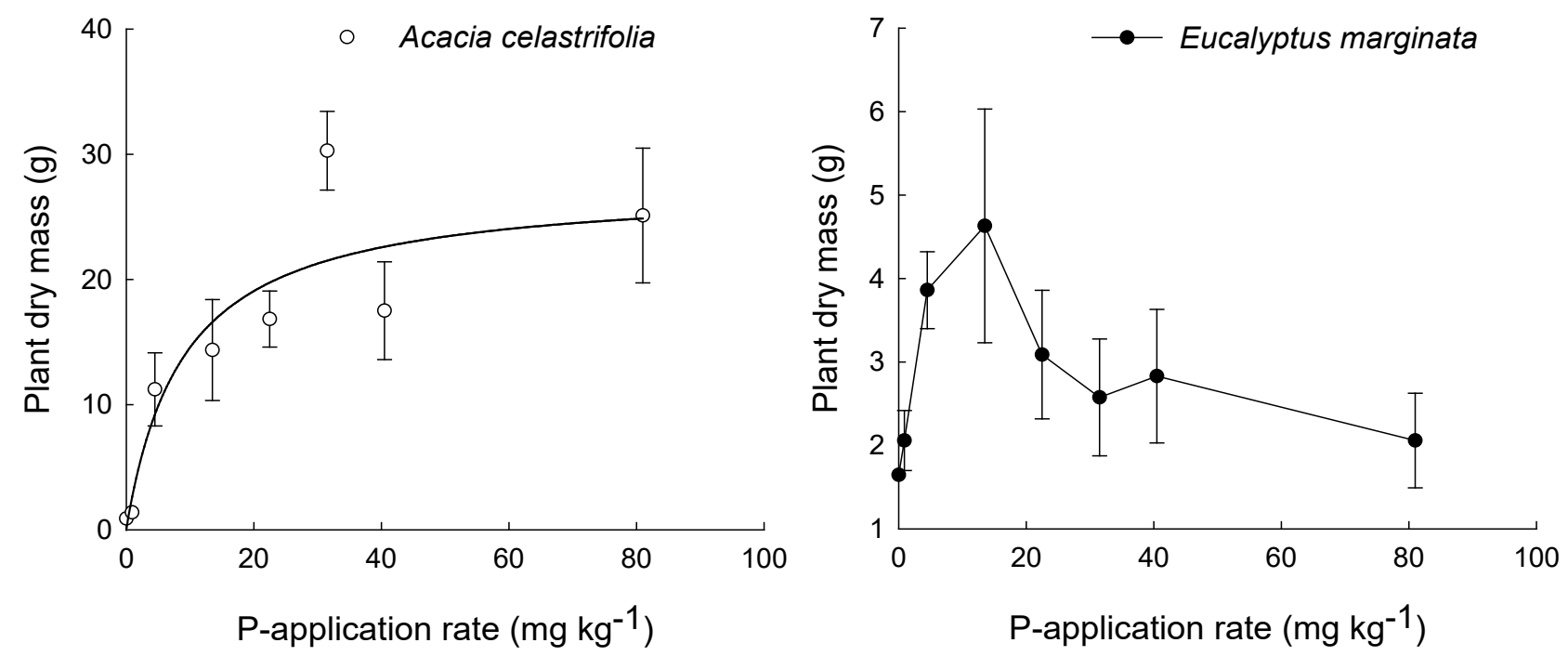

Figure 2 The effect of $P$ applied on dry mass of two woody species from the Jarrah Forest (Acacia celastrifolia and Eucalyptus marginata) grown for 187 days in washed river sand at a range of external soil $\mathrm{P}$ concentrations. Means +/- standard error

For the Jarrah Forest species, the $\mathrm{P}$ taken up into the plant tissue was notably different between species (Figure 3). The Acacia celastrifolia was clearly able to regulate its internal $\mathrm{P}$ concentration, whereas jarrah lost control of $\mathrm{P}$ accumulation under $\mathrm{P}$ oversupply and tissue concentration accumulated well into the toxic range (Shane et al. 2004). This may lead to further effects in plant community establishment as sub-lethal toxicities depressing growth for key species may lead to an initial bias in the growth of some species with potential long-term competitive implications: a form of founder effect. Consequently, when undertaking rehabilitation with plants adapted to nutrient deficient soils, there may be little benefit to growth from adding $\mathrm{P}$ fertiliser and potentially negative effects on growth and survival for a range of species.

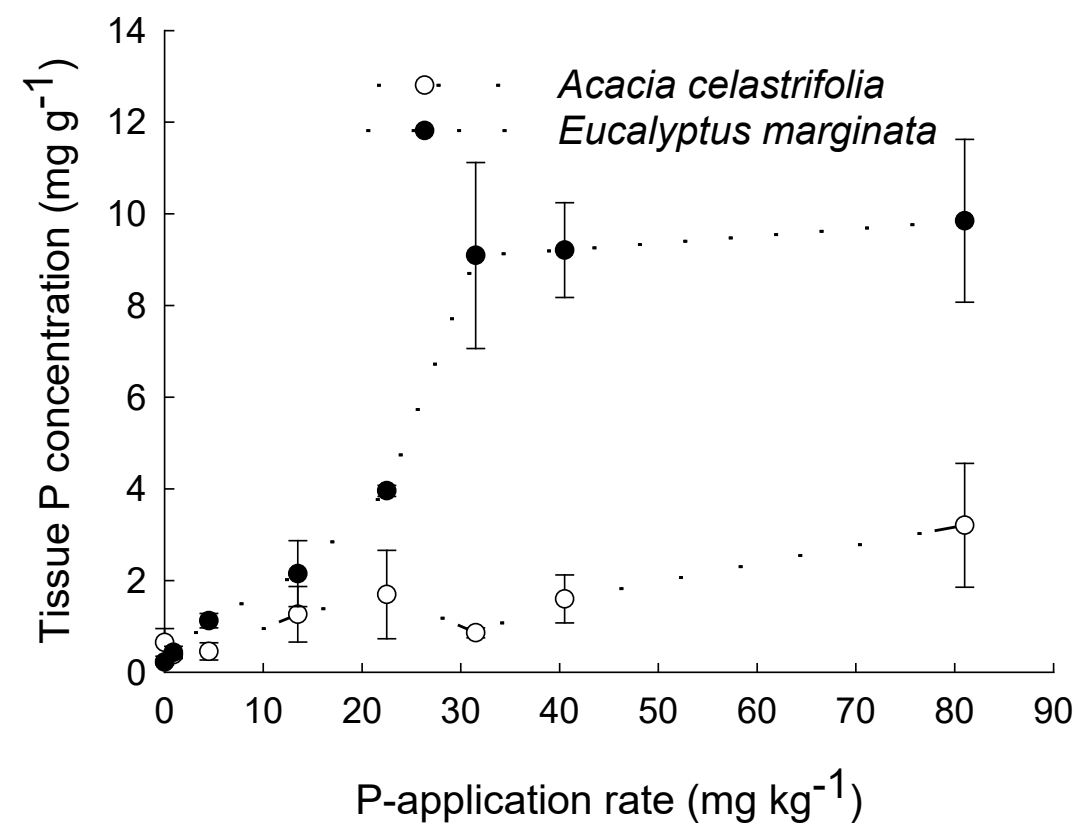

Figure 3 The effect of applied $\mathrm{P}$ on tissue $\mathrm{P}$ concentration of two woody species from the Jarrah Forest (Acacia celastrifolia and Eucalyptus marginata) grown for 187 days in washed river sand at a range of external soil $\mathrm{P}$ concentrations. Means $+/$ - standard error 


\subsection{Evidence for undesirable plant community outcomes}

Given the long-term residual available $P$ found in the fertilised soil and the sensitivity to $P$ of some key plant species used for land rehabilitation, it may not be surprising that there is an impact on plant communities. In a study of a 15-year chronosequence of plant community development at Boddington bauxite mine, we have previously shown how a restored Jarrah Forest community changes with time after rehabilitation using a non-metric, multidimensional scaling ordination (George et al. 2009; Figure 4). Ideally, with increasing forest age, we would anticipate that the forest community would become closer to the community of the surrounding native forest. However, we found the opposite occurring, and the plant community drifting away from the native forest with time. We hypothesised that this unfavourable change in the developing plant community was caused by excess $P$ fertilisation.

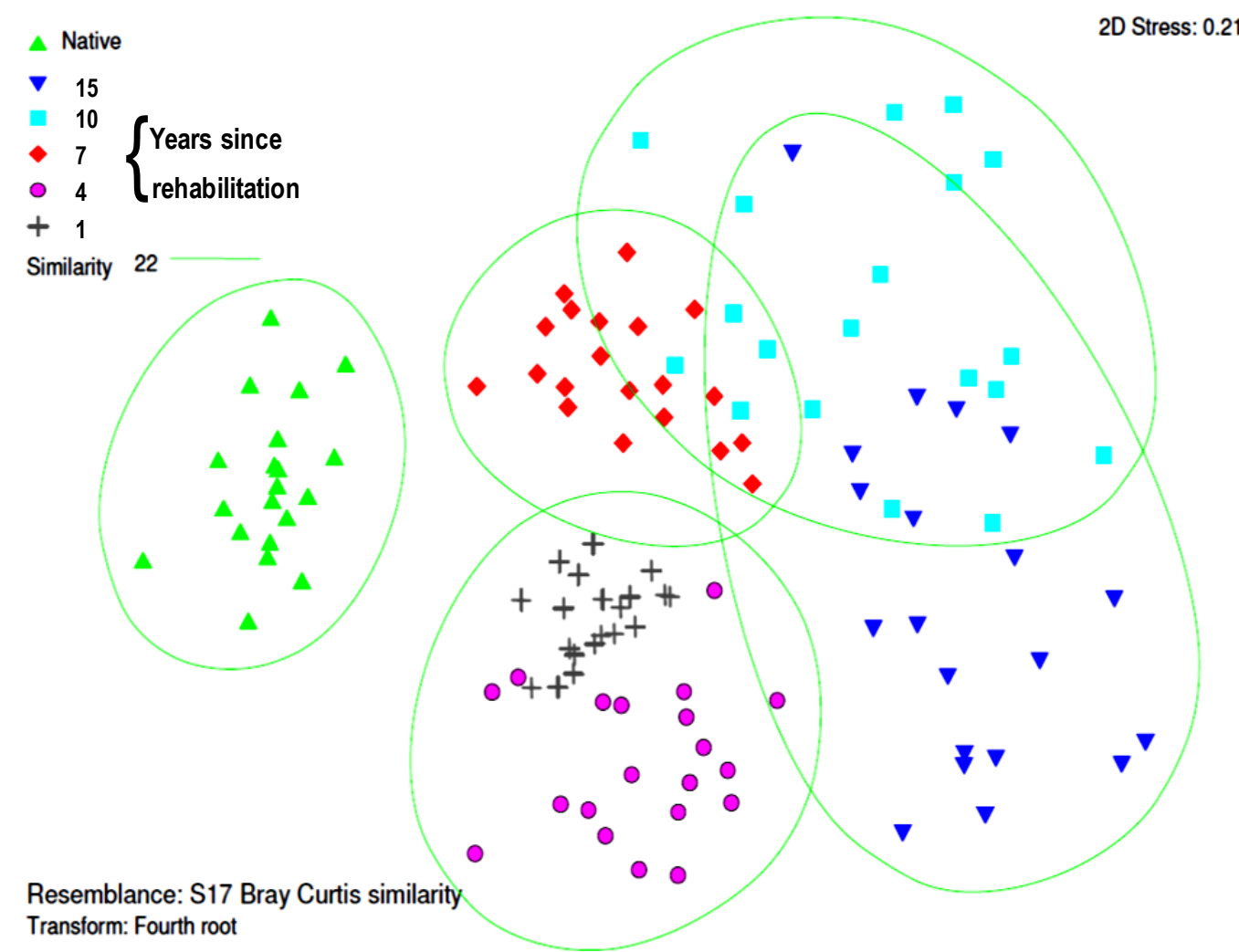

Figure 4 Ordination of multivariate species abundance data from rehabilitated sites and native forest site using a non-metric, multidimensional scaling. The circle represents an arbitrary similarity level using group-average linking on Bray-Curtis similarity data of $22 \%$ similarity contour. Raw data was subjected to a fourth-root transformation followed by Bray-Curtis similarity calculated between all pairs of observation (after George et al. 2006)

We have shown that over-fertilisation with $\mathrm{P}$ can cause plant toxicity but can it alter the manner in which plant communities develop? Recent papers have provided strong evidence that this may be the case at a community level (e.g. George et al. 2006; Daws et al. 2013, 2015, 2019a, 2019b). We were interested to test whether this could be seen when testing field grown species in pairwise comparisons (fertilised versus unfertilised) of percentage cover approximately one year after $\mathrm{P}$ amendment (for details, see George et al. 2006). We tested this with four species where either zero $P$ or $40 \mathrm{~kg} \mathrm{P} \mathrm{ha}^{-1}$ of single super phosphate fertiliser was applied in summer and then incorporated into the soil. Our test species were:

1. Acacia celastrifolia (Fabaceae), an early successional $\mathrm{P}$ responsive $\mathrm{N}$-fixer.

2. Banksia grandis (Proteaceae), a mid-storey tree know to be sensitive to $P$ (Lambers et al. 2002). 
3. Lomandra spp. (Dasypogonaceae), which are slow growing grass-like re-sprouter species that are abundant in unmined forest and under-represented in restored sites (e.g. Norman et al. 2006; Koch 2007).

4. Bossiaea ornata (Fabaceae), a small understorey legumous re-sprouter shrub.

We found considerable differences in the percentage cover in three of the four plants taxa examined. Most remarkable was the change in the percentage cover of the $\mathrm{N}$-fixing shrub Acacia celastrifolia. Without an exogenous $\mathrm{P}$ supply, it struggled to establish substantial cover, however, when fertilised, it dominated the cover of all the establishing plants (Figure 5). For Bossiaea ornata and Lomandra spp., the opposite response was found, with P application significantly inhibiting their coverage compared to unfertilised ground. Banksia grandis, known to be particularly sensitive to P supply in pot experiments (Lambers et al. 2002), did not show any difference in percentage cover after one year under high $\mathrm{P}$ fertilisation. This is also consistent with what has been found for 2.5-year-old Banksia grandis when 10-40 kg ha-1 $\mathrm{P}$ were applied to rehabilitated Jarrah Forest (Daws et al. 2013).
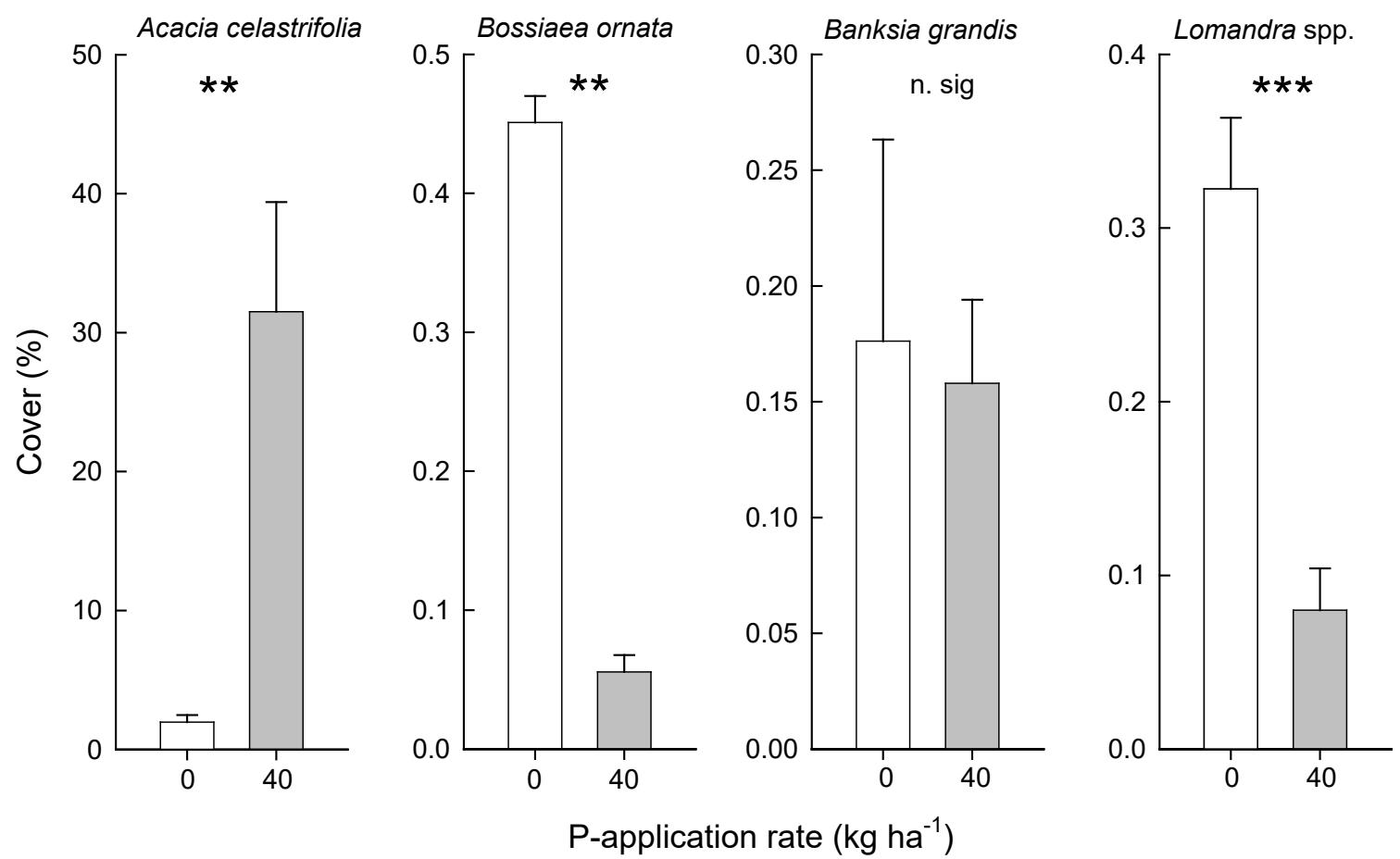

Figure 5 Mean percentage cover of four Jarrah forest taxa after one year after field trial initiation where treatments were either no phosphorus fertiliser or $40 \mathrm{~kg}$ ha-1 phosphorus applied as single super phosphate in a single dose $\left.{ }^{* * \mathrm{P}}<0.01,{ }^{* * *} \mathrm{P}<0.001\right)$. For Lomandra spp., six species were assessed and combined for a genus response

Compared with highly responsive species, such as Acacia celastrifolia, those species unable to respond positively in terms of growth to $\mathrm{P}$ fertiliser or that are inhibited by $\mathrm{P}$ fertilisation-either through sub-lethal toxicity, competition or both-will be at a clear competitive disadvantage in rehabilitated forests. These mechanisms may well explain why the Jarrah Forest community (Figure 4) has adjusted to a different community to that of native forests. The use of $\mathrm{P}$ fertiliser may therefore, have undesirable effects on certain plant communities that have evolved on ancient, low $\mathrm{P}$ soils. We suggest some reconsideration is given to current fertiliser practice in rehabilitation schemes in southwest Western Australia and further afield, where similar soils and concomitant ecosystems have evolved.

\subsection{Co-occurrence of strip mines and ancient, biodiverse ecosystems}

It is largely ancient, highly weathered soils or nutrient depleted sands that contain resources such as bauxite, iron ore, and mineral sands, with typically near-surface ores, that are strip-mined over large areas causing a 
greater land-take than conventional open pit and underground mines. For bauxite mining, for example, the worldwide use of new land mined was $30-50 \mathrm{~km}^{2} \mathrm{pa}$. A survey covering the period 2002-2006, showed that the land area rehabilitated corresponded to the land mined, during this period (Wagner 2016).

The paucity of $P$ in these landscapes it a critical feature of their biogeochemistry and ecology. This is an ecosystem response to Liebig's Law of the Minimum, originally applied to plant nutrition. This law principally states that if one of the essential plant nutrient is deficient, plant growth will be limited even when all other essential nutrients are abundant. In ancient soils and very old, climatically buffered, infertile landscapes (OCBILs) (Hopper 2009), the biology of the ecosystem has adapted to P starvation often over millions of years. OCBILs themselves are rare and occur mainly in the southern and tropical zones, and are quite commonly found on soil types known for their great age and P infertility, including Acrisols, Luvisols, Ferralsols, and Lixisols (see Appendix). OCBILs also overlap significantly with the world's biodiversity hotspots (Mittermeier et al. 2011; Treurnicht 2017). OCBILs occur in at least 12 out of 35 known terrestrial hotspots and in other biologically significant sites. The major sites of occurrence are the Southwest Australian and Greater Cape Floristic Regions, South America's Pantepui, and the Campo Rupestre of Brazil. Further predictions of the OCBIL theory have been documented in 22 locations throughout South America, Western and Eastern Africa, Southern Asia, and Oceania (Hopper et al. 2016).

Bauxite, iron ore, and mineral sands mining usually require soil types that typify OCBILs and/or many biodiversity hotspots. Here we have examined the geographic overlap between ancient soils, OCBILs, biodiversity hotspots, and strip mining operations using the following methods in QGIS (QGIS 2019). A map containing 846 terrestrial ecoregions (Dinerstein et al. 2017) was downloaded (https://ecoregions2017.appspot.com/). From this layer, all ecoregions identified as OCBIL by Hopper et al. (2016) were extracted as a single vector layer. The Harmonised World Soil Database v.1.2 rasterdatabase was download from the FAO Soils Portal (Food and Agriculture Organization of the United Nations 2012) converted into a vector layer, and the global coverage of Acrisols, Ferralsols, Lixisols, and Luvisols was extracted as a new layer. Global data on the known location of mineral resource deposits for bauxite, iron ore, zircon, and coal that would operate as surface mines were downloaded from the U.S. Geological Survey Mineral Resources Data Systems (https://mrdata.usgs.gov/mrds/). This shows deposits were producing, had produced, or were prospective as of 2011. These data were then merged into a single layer and clipped using the OCBILs and the data extracted to visualise and tabulate the occurrence of different deposit types in different OCBILs. A vector layer showing the coverage of the world's 36 biodiversity hotspots created by the Critical Ecosystems Partnership Fund (Critical Ecosystem Partnership Fund 2019) was also added to visualise the degree of overlap. All GIS analysis was conducted in QGIS version 3.4.5. (Figure 6). 


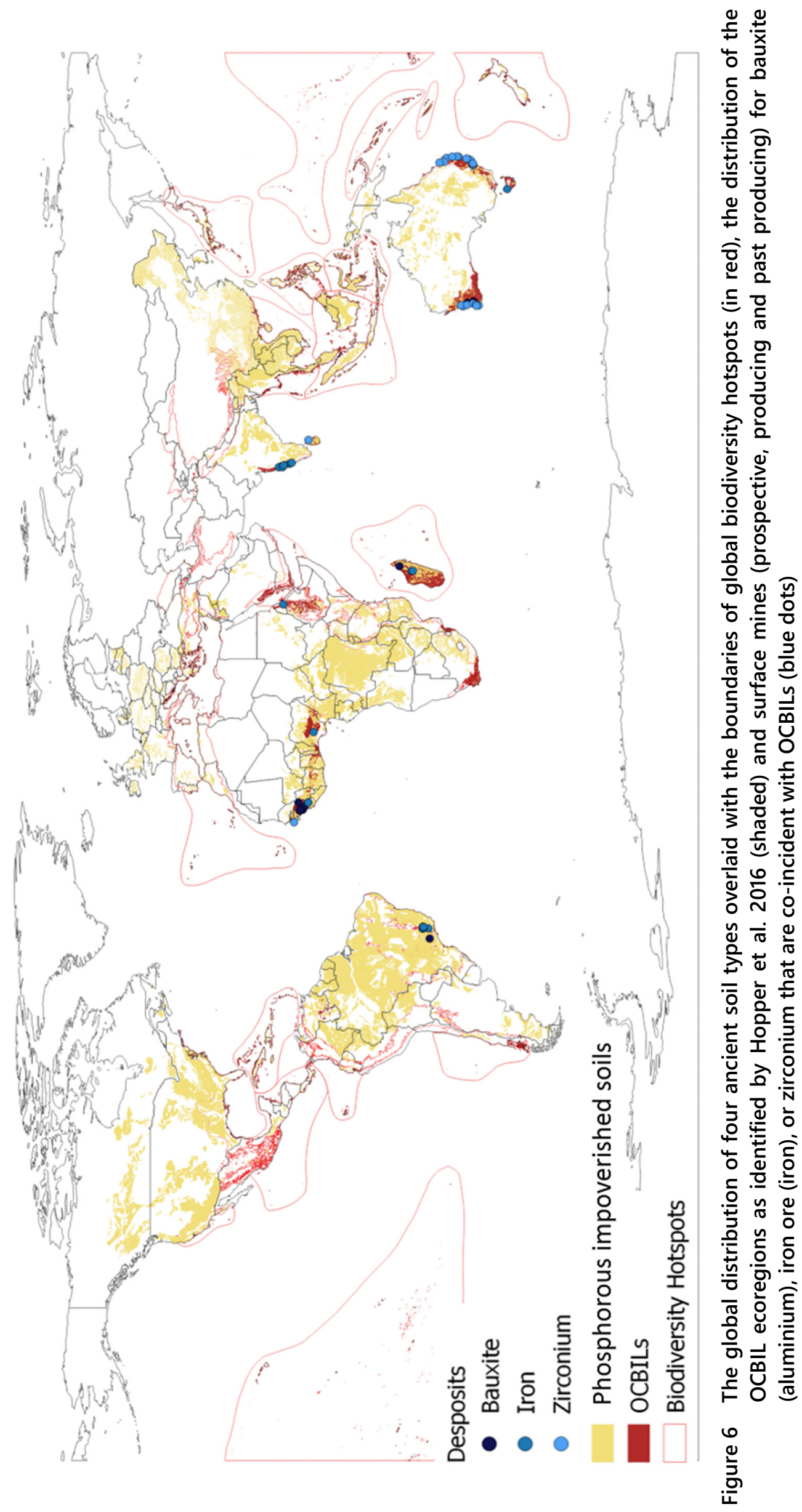




\subsubsection{Mapping co-occurrence}

The global distribution of ancient soil types overlaid with the boundaries of global biodiversity hotspots, the distribution of the OCBIL ecoregions, and surface mines for bauxite, iron ore, or zirconium that are co-incident with OCBILs are shown in (Figure 6). While the soils boundaries for many of the soil types are much wider than the OCBILs and biodiversity hotspots, they always overlap in key regions where surface strip mining is present. We found 72 mines in 10 countries with OCBILs in which bauxite, iron ore, or zirconium is mined (Table 2). These overlaps provide a backdrop for the classic conflict between mining and conservation (Murguía et al. 2016; Sonter et al. 2018; Tibbett 2015; Spain et al. 2015).

It is notable that the majority of soils we have identified as ancient and low in P (denoted as coloured areas in the Figures) occur predominantly in the southern hemisphere and the tropics. The distribution of mines within OCBILs and hotspots tend to aggregate around the ancient soil types in particular. A recent study, focused on base metal mining and global biodiversity hotspots, found that mines and deposits are not randomly distributed, but concentrated within intermediate and high biodiversity zones (Murguía et al. 2016).

Table 2 The number of surface mines (prospective, producing, and past producing) for bauxite, iron ore, or zirconium found in OCBILs separated by country (72 mines in total)

\begin{tabular}{llll}
\hline & \multicolumn{2}{l}{ Deposit type } & \\
Country & Bauxite & Iron ore & Zirconium \\
\hline Australia & 5 & 1 & 25 \\
Brazil & 2 & 14 & - \\
Ethiopia & - & 1 & - \\
Guinea & 6 & - & - \\
India & 3 & 7 & - \\
Madagascar & 1 & 2 & - \\
Nigeria & - & 1 & - \\
Senegal & - & - & 1 \\
Sierra Leone & 1 & 1 & - \\
Sri Lanka & - & - & 1 \\
Total & $\mathbf{1 8}$ & $\mathbf{2 7}$ & $\mathbf{2 7}$ \\
\hline
\end{tabular}

On a regional basis, far greater detail can be seen and there is a remarkable coincidence between soil types, OCBILs, biodiversity hotspots, and strip mining activities. On the west coast of Australia (Figure 7), a clear direct relationship can be seen between the iron and aluminium rich Ferralsols and bauxite mining. This soil type demarcates the Jarrah forests; the system from which the data on fertilisation experiments and vegetation development are based (Table 1; Figures 2, 3 and 4). Likewise, zirconium mines in both east and west Australia commonly occur on Acrisols. In all cases, these mines are found within OCBIL and biodiversity demarcated areas. 


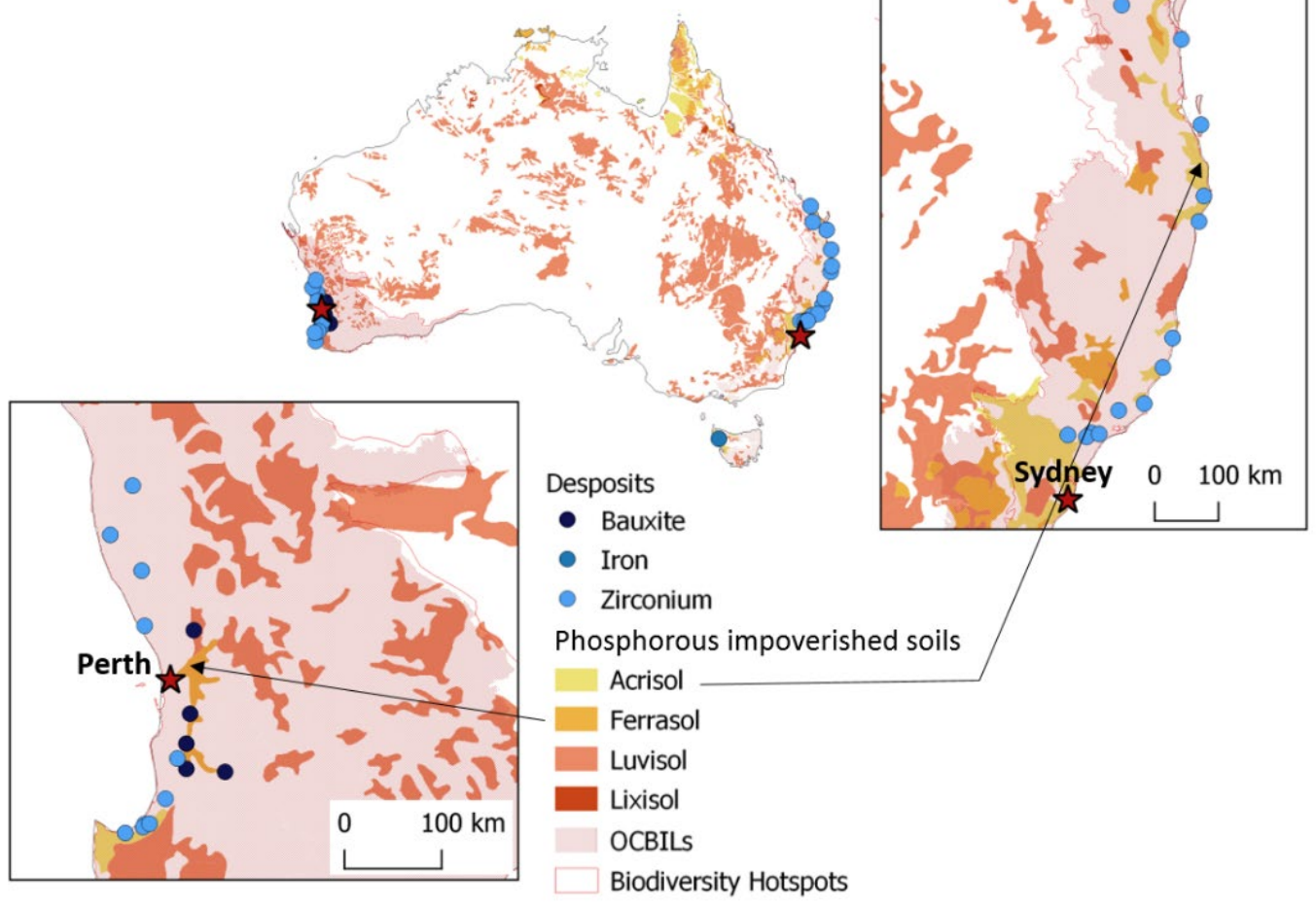

Figure 7 The distribution of four ancient soil types across Australia overlaid with the boundaries of global biodiversity hotspots (in red), the distribution of the OCBIL ecoregions as identified by Hopper et al. 2016 (shaded), and surface mines (prospective, producing and past producing) for bauxite (Aluminium), iron ore (Iron) or zirconium that are co-incident with OCBILs (blue dots).The left panel shows a close-up of the OCBIL ecoregions of the southwest Australian savannah, Esperance mallee, southwest Australia woodlands and the jarrah-karri forest and shrublands. The right-hand panel shows a close-up of the OCBIL ecoregion of the eastern Australian temperate forests

\section{Conclusion}

Our compilation of experimental data indicate that based on studies spanning western and northern Australia, the addition of P fertiliser to rehabilitated sites can result in long-term impacts on soil P-availability. For example, the addition of even moderate $\mathrm{P}$ fertiliser can result in soil $\mathrm{P}$ remaining elevated, compared with reference forest sites after 17 or more years (this study; Daws et al. 2019b). We have also shown that P-addition can result in both positive and negative effects on plant growth, dependent on species, with the potential to impact competitive interactions in a field setting. Further, for some species, negative effects of applied $\mathrm{P}$ on plant growth have the potential to be exacerbated with increased competition from species that respond vigorously to applied $P$ (e.g. some legumes).

Our selected soil types are low in P. It is well recognised that as landscapes age, weathering processes deplete P from soil profiles as part of long-term pedogenesis (Johnson et al. 2003; Selmants \& Hart 2010). In a well-established conceptual model describing this process, Walker \& Syers (1976) showed how various forms of $\mathrm{P}$ become depleted, diminishing total soil $\mathrm{P}$ over long periods of weathering. We have adapted this model (Figure 8) to posit that the fertilisation of ancient soils can serve to reverse this process and set the $P$ clock back to an earlier period of soil and ecosystem development. As $\mathrm{P}$ is so slowly lost from soils, this may have potential long-term and important implications on plant community, and even whole ecosystem, development for many years to come, and this highlights the necessity for judicious and justified $P$ fertilisation to restore ecosystem on OCBIL landscapes. 


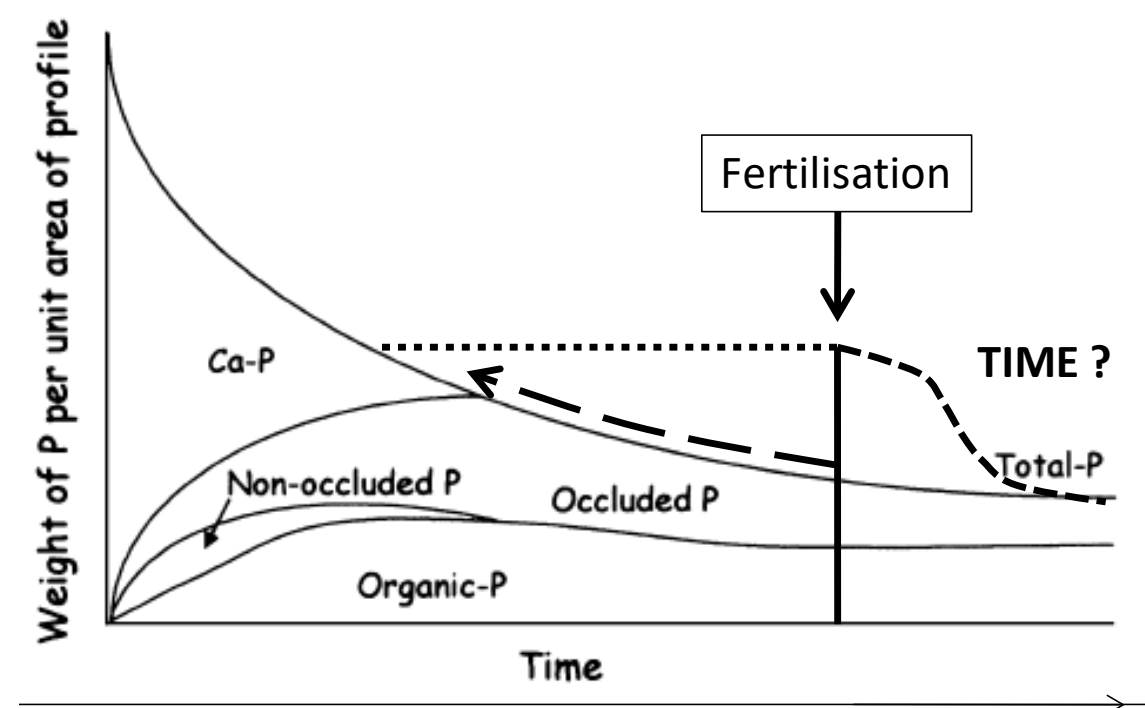

Figure 8 Conceptual model of phosphorus dynamics during long-term ecosystem development and its potential reversal when applied to soil on ancient ecosystems. Figure adapted from Walker \& Syers (1976)

Our finding and concepts may have global implication and we have shown that there is significant overlap between regions with naturally P-deficient soils, high plant diversity, and current and potential strip mining operations. This suggests there may be many more rehabilitation schemes either completed, in operation, or planned that are subject to the over-fertilisation of $\mathrm{P}$ leading to sub-optimal ecological outcomes with potentially long-term effects. As a result, the use of $\mathrm{P}$ fertiliser in rehabilitation, with a goal of increasing initial plant growth and establishment, warrants much closer investigation and assessment in these OCBIL regions to minimise possible negative effects on the resulting ecosystems.

\section{Acknowledgement}

This work was supported by the Building Outstanding Impact Support Programme H\&F38: Restoring biodiversity to phosphorus sensitive forests. 


\section{Appendix: Characteristics of ancient soil types}

Acrisols are found in ancient landscapes that have an undulating topography and a humid tropical climate. Typical vegetation consists of woodlands and open canopy tree savannahs. Acrisols are defined by the presence of a subsurface layer of accumulated kaolinitic clays where less than half of the ions available to plants are calcium, magnesium, sodium, or potassium and also by the lack of an extensively leached layer below the surface horizon. The age, mineralogy, and extensive leaching of these soils have led to low levels of plant nutrients, excess aluminium, and high erodibility. They occupy close to $8 \%$ of global land predominantly in central and northern Latin America, Southeast Asia, and West Africa. They are related taxonomically to the Oxisol soil Order of the U.S. Soil Taxonomy.

Lixisols develop on old landscapes in a tropical climate with a pronounced dry season. Their age and mineralogy have led to low levels of plant nutrients and a high erodibility. Lixisols are defined by the presence of a subsurface layer of accumulated kaolinitic clays. They occupy just under $3.5 \%$ of the continental land area on Earth, mainly in east-central Brazil, India, and West Africa. They are related to the Oxisol order of the U.S. Soil Taxonomy.

Ferralsols are red and yellow weathered soils whose colours result from an accumulation of metal oxides, particularly iron and aluminium. Ferralsols are defined by a fine-textured subsurface layer of low silt-to-clay ratio, high contents of kaolinitic clay, and iron and aluminium oxides. They are formed on geologically old parent materials in humid tropical climates, with rainforest vegetation growing in the natural state. They have low fertility and occupy less than $6 \%$ of the continental land surface on Earth and are located mainly in Brazil, the Congo River basin, Guinea, and Madagascar. Ferralsols are related to the Oxisol order of the U.S. Soil Taxonomy.

Luvisols are of mixed mineralogy and good drainage and form on flat or gently sloping landscapes under climatic regimes that range from cool temperate to warm Mediterranean. Luvisols are characterised by a surface accumulation of humus overlying an extensively leached layer that is nearly devoid of clay and ironbearing minerals. Occupying just over $5 \%$ of the total continental land area on Earth, they are found typically in west-central Russia, the United States, central Europe, the Mediterranean basin, and southern Australia. 


\section{References}

Banning, NC, Grant, CD, Jones, DL \& Murphy, DV 2008, 'Recovery of soil organic matter, organic matter turnover and nitrogen cycling in a post-mining forest rehabilitation chronosequence', Soil Biology and Biochemistry, vol. 40, pp. 2021-2031.

Braimbridge, M \& Tibbett, M 2005, Fertiliser application to native forest rehabilitation at BBM Interim Report - Field Trial Establishment, Unpublished report CLR-04-12-C to Worsley Alumina by the Centre for Land Rehabilitation, The University of Western Australia, Perth, p. 19.

Brenner, J, Porter, W, Phillips, JR, Childs, J, Yang, X \& Mayes, MA 2019, 'Phosphorus sorption on tropical soils with relevance to Earth system model needs', Soil Research, vol. 57, pp. 17-27.

Critical Ecosystem Partnership Fund 2019, Biodiversity Hotspots Defined, https://www.cepf.net/our-work/biodiversityhotspots/hotspots-defined

Daws, MI \& Richardson, C 2015, An operational scale assessment of the effects of a reduction in fertiliser application rates on plant species responses in jarrah forest restored after bauxite mining, Alcoa of Australia Ltd., Research Note No. 38.

Daws, MI, Grigg, AH, Standish, RJ \& Tibbett, M 2019b, 'Applied phosphorus has long-term impacts on vegetation responses in restored jarrah forest', in AB Fourie \& M Tibbett (eds), Proceedings of the 13th International Conference on Mine Closure, Australian Centre for Geomechanics, Perth, pp. 693-704.

Daws, MI, Grigg, AH, Tibbett, M \& Standish, RJ 2019a, 'Enduring effects of large legumes and phosphorus fertiliser on jarrah forest restoration 15 years after bauxite mining', Forest Ecology and Management, vol. 438, pp. 204-214.

Daws, MI, Richardson, C \& Standish, RJ 2014, Effects of nitrogen and phosphorus on understorey vegetation and tree growth five years after fertiliser addition, Alcoa of Australia Ltd., Research Note No. 37.

Daws, MI, Standish, RJ, Koch, JM \& Morald, TK 2013, 'Nitrogen and phosphorus fertiliser regime affect jarrah forest restoration after bauxite mining in Western Australia', Applied Vegetation Science, vol. 16, pp. 610-618.

Daws, MI, Standish, RJ, Koch, JM, Morald, TK, Tibbett, M \& Hobbs, RJ 2015, 'Phosphorus fertilisation and large legume species affect jarrah forest restoration after bauxite mining', Forest Ecology and Management, vol. 354, pp. 10-17.

de Campos, MCR, Pearse, J, Oliveira, RS \& Lambers, H 2013, 'Downregulation of net phosphorus-uptake capacity is inversely related to leaf phosphorus-resorption proficiency in four species from a phosphorus-impoverished environment', Annals of Botany, vol. 111, pp. 445-454.

Dinerstein, E, Olson, D, Joshi, A, Vynne, C, Burgess, ND, Wikramanayake, E, ... Kindt, R 2017, 'An ecoregion-based approach to protecting half the terrestrial realm', Bioscience vol. 67, pp. 534-545.

Food and Agriculture Organization of the United Nations 2012, Harmonized World Soil Database v 1.2, http://www.fao.org/soilsportal/soil-survey/soil-maps-and-databases/harmonized-world-soil-database-v12/en/

George, SJ, Kelly, R, Greenwood, P \& Tibbett, M 2009, 'Is soil carbon being sequestered along a reconstructed biodiverse Australian Jarrah Forest chronosequence following bauxite mining?', in AB Fourie \& M Tibbett (eds), Proceedings of the Fourth International conference Mine Closure, Australian Centre for Geomechanics, Perth, pp. 137-144.

George, SJ, Tibbett, M, Braimbridge, MF, Davis, SG, Vlahos, S \& Ryan, M 2006, 'Phosphorus fertiliser placement and seedling success in Australian jarrah forest', in AB Fourie \& M Tibbett (eds), Proceedings of the First International Seminar on Mine Closure, Australian Centre for Geomechanics, Perth, pp. 341-350.

Handreck KA 1997, 'Phosphorus requirements of Australian native plants', Australian Journal of Soil Research, vol. 35, pp. 241-289.

Handreck, KA 1991, 'Interactions between iron and phosphorus in the nutrition of Banksia ericifolia L. f. var. ericifolia (Proteaceae) in soil-less potting media', Australian Journal of Botany, vol. 39, pp. 373-384.

Hopper, SD 2009, 'OCBIL theory: towards an integrated understanding of the evolution, ecology and conservation of biodiversity on old, climatically buffered, infertile landscapes', Plant and Soil, vol. 322, pp. 49-86.

Hopper, SD, Silveira, FA \& Fiedler, PL 2016, 'Biodiversity hotspots and Ocbil theory', Plant and Soil, vol. 403, pp. $167-216$.

Johnson, AH, Frizano, J \& Vann, DR 2003, 'Biogeochemical implications of labile phosphorus in forest soils determined by the Hedley fractionation procedure', Oecologia, vol. 135(4), pp. 487-499.

Koch, JM 2007, 'Restoring a Jarrah forest understorey vegetation after bauxite mining in Western Australia', Restoration Ecology, vol. 15, pp. S26-S39.

Lambers H, Raven JA, Shaver GR \& Smith SE 2008, 'Plant nutrition-acquisition strategies change with soil age', Trends in Ecology and Evolution, vol. 23, pp. 95-103.

Lambers H, Shane MW, Cramer MD, Pearse SJ \& Veneklaas EJ 2006, 'Root structure and functioning for efficient acquisition of phosphorus: matching morphological and physiological traits', Annals of Botany vol. 98, pp. 693-713.

Lambers, H, Juniper, D, Cawthray, GR, Veneklaas, EJ \& Martínez-Ferri, E 2002, 'The pattern of carboxylate exudation in Banksia grandis (Proteaceae) is affected by the form of phosphate added to the soil', Plant and Soil, vol. 238, pp. 111-122.

Marschner, H 1995, Mineral nutrition of higher plants, 2nd edn. Academic Press, London.

Mittermeier, RA, Turner, WR, Larsen, FW, Brooks, TM \& Gascon, C 2011, 'Global biodiversity conservation: the critical role of hotspots', in E Zachos \& JC Habel (eds), Biodiversity hotspots: distribution and protection of conservation priority areas, Springer, Berlin, pp 3-22.

Morley, S, Grant, C, Hobbs, R \& Cramer, V 2004, 'Long-term impact of prescribed burning on the nutrient status and fuel loads of rehabilitated bauxite mines in Western Australia', Forest Ecology and Management, vol. 190, pp. 227-239.

Murguía, DI, Bringezu, S \& Schaldach, R 2016, 'Global direct pressures on biodiversity by large-scale metal mining: spatial distribution and implications for conservation', Journal of Environmental Management, vol. 180, pp. 409-420.

Norman, MA, Koch, JM, Grant, CD, Morald, TK \& Ward, SC 2006, 'Vegetation succession after bauxite mining in Western Australia', Restoration Ecology, vol. 14, pp. 278-288. 
Pang, JY, Tibbett, M, Denton, MD, Lambers, H, Siddique, KHM, Bolland, MDA, ... \& Ryan, MH 2010, 'Variation in seedling growth of 11 perennial legumes in response to phosphorus supply', Plant and Soil, vol. 328, pp. 133-143.

QGIS 2019, Open Source Geographic Information System, version 3.4.5, computer software, QGIS, http://qgis.osgeo.org

Raghothama, KG 1999, 'Phosphate acquisition', Annual Review of Plant Physiology and Plant Molecular Biology, vol. 50 pp. 665-693.

Ryan, MH, Tibbett, M, Lambers, H, Bicknell, D, Brookes, P, Barrett-Lennard, EG, ... \& Nicol, D 2017, 'Pronounced surface stratification of soil phosphorus, potassium and sulfur under pastures upstream of a eutrophic wetland and estuarine system', Soil Research, vol. 55, pp. 657-669.

Sanyal, SK \& De Datta, SK 1991, 'Chemistry of phosphorus transformations in soil', Advances in Soil Science, Springer, New York, pp. 1-120.

Selmants, P \& Hart, S 2010, 'Phosphorus and soil development: Does the Walker and Syers model apply to semiarid ecosystems?', Ecology, vol. 91(2), pp. 474-484.

Shane, MW, Szota, C \& Lambers, H 2004, 'A root trait accounting for the extreme phosphorus sensitivity of Hakea prostrata (Proteaceae)', Plant Cell and Environment, vol. 27, pp. 991-1004.

Sonter, LJ, Ali, SH \& Watson, JE 2018, 'Mining and biodiversity: key issues and research needs in conservation science', Proceedings of the Royal Society B, vol. 285.

Spain, AV, Tibbett, M, Hinz, DA, Ludwig, JA \& Tongway, DJ 2015, 'The mining restoration system and ecosystem development following bauxite mining in a biodiverse environment of the seasonally dry tropics, Northern Territory, Australia', in M Tibbett (ed.), Mining in Ecologically Sensitive Landscapes, CRC Press, Netherlands, pp. 159-227.

Spain AV, Tibbett M, Ridd M \& McLaren TI 2018, 'Phosphorus dynamics in a tropical forest soil restored after strip mining', Plant \& Soil, vol. 427, pp. 105-123.

Standish, RJ, Tibbett, M, Vlahos, S, Stokes BA \& Hobbs, RJ 2010, 'The effect of fertiliser on floristic diversity and composition of earlysuccessional jarrah forest restored after bauxite mining in south-western Australia', in AB Fourie, M Tibbett \& J Wiertz (eds), Proceedings of the Fifth International Conference Mine Closure, Australian Centre for Geomechanics, Perth, pp 387-395.

Standish, RJ, Morald, TK, Koch, JM, Hobbs, RJ \& Tibbett, M 2008, 'Restoring jarrah forest after bauxite mining in Western Australia: the effect of fertiliser on floristic diversity and composition', in AB Fourie, M Tibbett, IM Weiersbye \& PJ Dye (eds), Proceedings of the Third International Seminar on Mine Closure, Australian Centre for Geomechanics, Perth, pp. 717-725.

Tibbett, M 2010, 'Large-scale Mine Site Restoration of Australian Eucalypt Forests After Bauxite Mining: Soil Management and Ecosystem Development', in LC Batty \& K Hallberg (eds), Ecology of Industrial Pollution, Cambridge University Press, Cambridge, pp. 309-326.

Tibbett, M 2015, 'Mining in ecological landscapes: concepts and challenges', in M Tibbett (ed.), Mining in Ecologically Sensitive Landscapes, CRC Press, Netherlands, pp. 1-6.

Tibbett, M \& George, SJ 2010, Fertiliser application to native forest rehabilitation at Boddington Bauxite Mine: Interim Report - Initial Soil Test Results and Floristic Diversity at Establishment, Unpublished report CLR-08-19-C to BHP Billiton Worsley Alumina Pty Ltd by the Centre for Land Rehabilitation, The University of Western Australia, Australia, p. 19.

Treurnicht, M, Colville, JF, Joppa, LN, Huyser, O \& Manning, J 2017, 'Counting complete? Finalising the plant inventory of a global biodiversity hotspot', PeerJ, https://doi.org/10.7717/peerj.2984

Wagner, C 2016, 'Sustainable Bauxite Mining-A Global Perspective', in D Donaldson \& BE Raahauge (eds), Essential Readings in Light Metals, Springer, Cham, pp. 54-59.

Walker TW \& JK Syers 1976, 'The fate of phosphorus during pedogenesis', Geoderma 15, pp. 1-19.

Ward, SC 2000, 'Soil development on rehabilitated bauxite mines in south-west Australia', Australian Journal of Soil Research, vol. 38, pp. 453-464.

Williams, A, George S, Birt, HWG, Daws, MI \& Tibbett, M 2019, 'Sensitivity of seedling growth to phosphorus supply in six tree species of the Australian Great Western Woodlands', Australian Journal of Botany, unpublished. 
